\title{
EVALUASI SIFAT FISIKA KIMIA DAN TANGGAP RASA TABLET HISAP DEKOKTA DAUN MENGKUDU (Morinda citrifolia L.) DENGAN VARIASI PEMANIS
}

\author{
M Fatchur Rochman*, Mufrod, Feyzar Habib Reynaldo, Ayuk Siti Fatimah, \\ Yayang Rusyta Dewi
}

\author{
Program Studi S1 Farmasi Fakultas Farmasi Universitas Wahid Hasyim \\ Jalan Menoreh Tengah x/22, Sampangan. Semarang \\ Email: rochmanmfatchur@gmail.com
}

\section{INTISARI}

Daun mengkudu (Morinda citrofolia L.) memiliki senyawa antioksidan yang mampu menghambat dan menangkal radikal bebas. Dekokta daun mengkudu supaya lebih praktis dibuat sediaan tablet hisap. Penelitian ini bertujuan untuk mengevaluasi sifat fisika kimia dan tanggap rasa tablet hisap dengan variasi pemanis untuk menutupi rasa pahit daun mengkudu.

Dekokta daun mengkudu diperoleh dengan cara perebusan pada suhu $900 \mathrm{C}$ selama 30 menit. Tablet hisap dibuat 9 formula berdasarkan variasi pemanis sukrosa-air tebu, sorbitol-sukrosa-air tebu, dan aspartam-sukrosa-air tebu. Tablet hisap dibuat dengan metode molding mixture. Evaluasi sifat fisika kimia meliputi kekerasan dan waktu larut dianalisis secara statistik menggunakan Anova satu jalan dengan taraf kepercayaan 95\%, dilanjutkan uji tukey, keseragaman bobot, tanggap rasa serta kromatografi lapis tipis dianalisis secara deskriptif.

Hasil penelitian tablet hisap dekokta daun mengkudu dengan variasi pemanis sukrosa-air tebu, sorbitol-sukrosa-air tebu, dan aspartam-sukrosa-air tebu menunjukkan bahwa kenaikan sukrosa tidak mempengaruhi keseragaman bobot namun mempengaruhi kenaikan kekerasan dan waktu larut serta hasil penelitian memenuhi persyaratan sifat fisik tablet hisap Hasil uji KLT tablet hisap dan dekokta menunjukkan nilai RF yang mendekati Quersetin. Hasil uji tanggap rasa menunjukkan formula I dengan variasi pemanis sukrosa-air tebu, formula III dengan variasi pemanis sorbitol-sukrosa-air tebu dan aspartame-sukrosa-air tebu paling disukai responden sebesar $85 \%-95 \%$.

Kata kunci: daun mengkudu, morinda citrofolia 1., tablet hisap, sorbitol, aspartam, sukrosa, air tebu

\section{ABSTRACT}

Noni leaf (Morinda citrofolia L.) has antioxidant compounds that can inhibit and counteract free radicals. Decocta Noni leaf to make more practice preparation of lozenges. This study aims to evaluate the physical chemical characteristics and taste response of lozenges with variations of sweeteners to cover the bitter taste of Noni leaves.

Decocta mengkudu leaf is obtained by boiling at 90C for 30 minutes. Suction tablets made 9 formulas based on variations of sweeterners sucrose-water sweetener, sorbitol-sucrose-sugarcane water, and aspartame-sucrose-sugarcane water. The suction tablet is made by molding mixture method. Evaluation of physical chemical characteristics including hardness and solubility were analyzed statistically using one-way ANOVA with 95\% confidence level, followed by tukey test, weight uniformity, taste response and thin layer chromatography analyzed descriptively. 
The results of the study was showed that influenced the increase in hardness and dissolution time and the results of the requirements physical lozenges The results of the TLC test of lozenges and decocytes showed an RF value close to Quercetin. The taste response test results showed formula I with variations of sugarcane-sucrose water sweetener, formula III with variations in sorbitol-sucrose-sugarcane-water sweetener and sugarcane water aspartame-sucrose was the most preferred by respondents of $85 \%-95 \%$.

Keywords: leaf of morinda citrifolia l., lozenges, sorbitol, aspartame, sucrose, sugarcane water

*Corresponding author:

M Fatchur Rochman

Program Studi S1 Farmasi Fakultas Farmasi Universitas Wahid Hasyim

Jalan Menoreh Tengah x/22, Sampangan. Semarang

Email: rochmanmfatchur@gmail.com

\section{PENDAHULUAN}

Flavonoid yang terkandung dalam daun mengkudu terbukti memiliki aktivitas sebagai antioksidan dengan nilai IC50 123,72 $\mu \mathrm{g} / \mathrm{mL}$ (Abdul dkk., 2007). Antioksidan dalam tubuh bermanfaat untuk menghambat, mencegah, atau menangkal radikal bebas (Javanmardi dkk., 2003). Secara empiris, daun mengkudu digunakan dalam sediaan rebusan yang kurang praktis dan memiliki intensitas rasa yang pahit sehingga diformulasikan menjadi tablet hisap dengan variasi pemanis yaitu sukrosa-air tebu, sorbitol-sukrosa-air tebu, dan aspartame-sukrosa-air tebu sebagai pemanis untuk menutupi rasa pahit dari dekokta daun mengkudu diharapkan dapat diterima oleh incidental responden. Sifat fisik tablet hisap yang keras dapat mempengaruhi waktu larut lahan yang digunakan secara sistemik sehingga bentuk sediaan tablet hisap harus keras. Karakteristik pemanis sorbitol, aspartam, sukrosa dan air tebu. Sorbitol merupakan serbuk, berwarna putih, higroskopis, berasa manis, sangat mudah larut dalam air, sukar larut dalam etanol, methanol dan dalam asam asetat (Depkes RI, 1995). Aspartam merupakan berbentuk tepung kristal berwarna putih, serbuk yang tidak berbau, sedikit larut dalam air, dan berasa sangat manis (Rowe dkk., 2009). Sukrosa kristal tidak berwarna, tidak berbau, memiliki rasa yang manis dan larut dalam air (Rowe dkk., 2009). Air tebu memiliki tingkat kemanisan 25\% dari sukrosa. Air tebu memilik karakteristik dapat memberikan rasa manis, daya lekat tinggi, memperbaiki tekstur dan menjaga kualitas (Alikonis, 1979).

Penelitian serupa telah dilakukan oleh Alkarim dkk., (2012) tentang formulasi hard candy lozenges ekstrak daun legundi (Vitex trifolia L.) Hasil penelitian menunjukkan bahwa variasi konsentrasi sukrosa dan glukosa mempengaruhi sifat fisik hard candy lozenges ekstrak daun legundi yaitu meningkatkan kekerasan dan memperlama waktu yang diharapkan obat dapat lepas dengan perlahan- larut.semakin banyak sukrosa yang digunakan maka tablet menjadi semakin keras dan waktu larut semakin lama. Berdasarkan uraian latar belakang diatas dapat disimpulkan untuk mengetahui variasi pemanis sukrosa-air tebu, sorbitol-sukrosa-air tebu, dan aspartam-sukrosa-air tebu terhadap sifat fisik dan tanggap rasa pada sediaan tablet hisap dekokta daun mengkudu.

\section{METODE PENELITIAN}

\section{Bahan dan Alat}

Bahan yang digunakan dalam penelitian ini antara lain: daun mengkudu, minyak permen, air tebu hijau, sorbitol, aspartam, sukrosa dan aquadest. Alat yang digunakan dalam penelitian ini: alat timbang, gunting, tampah, blender, moisture content balance, ayakan serbuk, kompor listrik, panci dekokta, cawan porselen, neraca analitik, Spektrofotometer UV-Vis, hardness tester, magnetic stirrer, stopwatch, chamber, oven, dan alat-alat gelas.

\section{Jalannya Penelitian}

\section{Determinasi tanaman mengkudu dan tanaman tebu hijau}


Determinasi terhadap tanaman mengkudu dan tanaman tebu hijau dilakukan untuk memastikan bahwa tanaman yang digunakan dalam penelitian ini benar-benar daun mengkudu dan batang tebu hijau. Determinasi tanaman dilakukan di Laboratorium Ekologi dan Biosistemik Jurusan Biologi, Fakultas Matematika dan Ilmu Pengetahuan Alam, Universitas Diponegoro.

\section{Pengumpulan bahan daun mengkudu dan batang tebu hijau}

Daun mengkudu diperoleh dari daerah Mangkang, Semarang, Jawa Tengah. Daun mengkudu dipanen pada usia lebih dari 2 tahun. Batang tebu hijau diperoleh di daerah Kediri, Jawa Timur. Batang tebu dipanen pada usia 12 bulan. Waktu memanen dilakukan pada pagi hari (Badan Penelitian dan Pengembangan Pertanian Kementerian Pertanian, 2012).

\section{Pembuatan serbuk daun mengkudu}

Daun mengkudu disortasi basah, kemudian dicuci dengan air mengalir, kemudian dipotong kecil-kecil, selanjutnya dikeringkan di bawah panas matahari langsung selama 48 jam (Halimah, 2016). Simplisia kering dibuat serbuk dengan cara diblender kemudian diayak dengan ayakan ukuran mesh 20. Persyaratan kadar air pada simplisia kering sebelum dilakukan proses penyarian yaitu kurang dari $10 \%$. Prosedur pemeriksaan kadar air yaitu memasukkan lempeng ke dalam alat moisture content balance kemudian ditimbang 2 gram daun mengkudu alat ditutup dan diatur suhu $105^{\circ} \mathrm{C}$ kemudian ditunggu selama 15 menit angka kadar air muncul (Depkes RI, 1986).

\section{Pembuatan dekokta daun mengkudu}

Serbuk simplisia daun mengkudu ditimbang kurang lebih 500 gram dimasukkan dalam panci, ditambahkan cairan penyari aquadest sebanyak $5000 \mathrm{ml}$ (10 bagian bahan dalam 100 bagian serkaian) (Van Duin, 1947) direbus bersama air pada suhu $90-95^{\circ} \mathrm{C}$ selama 30 menit. setelah itu dekokta disaring untuk memisahkan daun dengan aquadest dekokta (Halimah, 2016).

\section{Pembuatan air tebu}

Pada penelitian ini air tebu diperoleh dengan menggunakan metode penggilingan. Batang tebu yang terpilih dilakukan proses penggilingan dengan menggunakan mesin penggiling. Peremasan dilakukan setiap pembuatan tablet hisap.

\section{Pemeriksaan sifat fisika dan kimia dekokta daun mengkudu dan air tebu}

Pemeriksaan sifat fisika dan kimia dekokta daun mengkudu dan air tebu meliputi :

a. Pemeriksaan Organoleptis

Pemeriksaan organoleptis dilakukan untuk mendapatkan data tentang bentuk, warna, bau dan rasa dekokta daun mengkudu dan air tebu yang dihasilkan.

b. Pemeriksaan Kejernihan

Air tebu yang diperoleh diuji kejernihan untuk mendeteksi adanya pengotor yang mempengaruhi kejernihan dengan pembanding air gula sedangkan dekokta daun mengkudu yang diperoleh diuji kejernihan untuk mendeteksi adanya pengotor yang mempengaruhi kejernihan dengan pembanding air teh.

c. Pemeriksaan KLT

Uji skrining fitokimia ditotolkan pada plat silika gel G60. Dielusi dengan n- heksana : etil asetat 2:1, kemudian dikeringkan diamati pada cahaya tampak, UV $254 \mathrm{~nm}$ dan $366 \mathrm{~nm}$. Selanjutnya plat di uapi dengan ammonia, dikeringkan dan diamati kembali pada cahaya tampak, UV $254 \mathrm{~nm}$ dan $366 \mathrm{~nm}$ (Annisa, 2010).

\section{Dosis dan formula tablet hisap}

Dosis dekokta daun mengkudu mengacu pada penelitian Abdul dkk., 2007 yang menyatakan bahwa aktivitas antioksidan daun mengkudu yang diekspresikan dengan nilai $\mathrm{IC}_{50}$ sampel uji fraksi air sebanyak $123,72 \mu \mathrm{g} / \mathrm{ml}$. perhitungan $\mathrm{IC}_{50}$ dikonversikan sehingga memperoleh dosis untuk manusia sebesar $824 \mathrm{mg}$. Formula tablet hisap dekokta daun mengkudu dapat dilihat pada tabel I. 
Tabel I. Formula Tablet Hisap Dekokta Daun Mengkudu (Morinda citrifolia L.) dengan Kombinasi Pemanis Sukrosa-Air Tebu, Sorbitol-Sukrosa-Air tebu, dan AspartamSukrosa-Air Tebu

\begin{tabular}{|l|c|c|c|c|c|c|c|c|c|}
\hline \multicolumn{1}{|c|}{ Bahan } & F1 & F2 & F3 & F4 & F5 & F6 & F7 & F8 & F9 \\
\hline $\begin{array}{l}\text { Dekokta daun } \\
\text { mengkudu (mg) }\end{array}$ & 824 & 824 & 824 & 824 & 824 & 824 & 824 & 824 & 824 \\
\hline Sukrosa (mg) & 1995 & 1425 & 855 & 885 & 1425 & 1995 & 885 & 1425 & 1995 \\
\hline Sorbitol (mg) & - & - & - & 280 & 200 & 120 & - & - & - \\
\hline Aspartam (mg) & - & - & - & - & - & - & 7 & 5 & 3 \\
\hline Air tebu (mg) & 885 & 1425 & 1995 & 2,04 & 1,55 & 1,06 & 2,31 & 1,74 & 1,18 \\
\hline Minyak permen (ml) & 0,065 & 0,065 & 0,065 & 0,065 & 0,065 & 0,065 & 0,065 & 0,065 & 0,065 \\
\hline Aquadest (ml) & 1 & 1 & 1 & - & - & - & - & - & - \\
\hline
\end{tabular}

\section{Pembuatan tablet hisap dengan metode molding mixture}

Tablet hisap dibuat dengan metode molding mixture. Sorbitol, Aspartam, dan Sukrosa yang telah ditimbang dilarutkan dengan aquadest dan air tebu dalam panci dipanaskan, kemudian ditambahkan dekokta sampai membentuk karamel. Setelah itu diangkat panci ditambah aspartam dan minyak permen dicampurkan dan diaduk hingga homogen, kemudian dituang kedalam cetakan dengan berat 2,5 gram dibiarkan sampai mengeras. Kemudian dikeluarkan dari cetakan dan dikemas. Penyimpanan dilakukan pada suhu kamar 350 hingga padat dan keras (Koswara, 2009).

\section{Pemeriksaan sifat fisika dan kimia tablet hisap dekokta daun mengkudu}

a. Keseragaman Bobot

Ditimbang 20 tablet hisap dekokta daun mengkudu satu persatu dengan neraca analitik, kemudian dihitung rata-rata, persen penyimpanan bobot, Standar Deviasi (SD) dan Coefficient Variation (CV) (Hidayah, 2016). Hasil dibandingkan dengan persyaratan yang ada dalam Farmakope Indonesia Edisi III. Tidak boleh lebih dari dua tablet bobotnya menimpang dari bobot rata-ratanya lebih dari $5 \%$ dan tidak ada satu tablet pun yang bobotnya menyimpang dari bobot rata- ratanya lebih dari 10\% (Depkes RI, 1979).

b. Kekerasan

Pemeriksaan kekerasan tablet hisap diletakkan pada posisi tegak lurus pada alat hardness tester, alat diverifikasi atau diatur sedemikian rupa sehingga tablet hisap stabil pada tempatnya dan jarum penunjuk pada skala 0 (Hidayah, 2016).

c. Waktu Larut

Air dipanaskan $200 \mathrm{ml}$ dalam beker glass ditambahkan magnetic stirrer dengan suhu 370C dengan kecepatan sekitar 50 rpm, tambahkan 1 tablet hisap kedalam air setelah 30 menit, catat pengamatan larut atau tidak (Allen, 2002).

d. Uji Tanggap Rasa Tablet Hisap oleh Incidental Responden

Pemeriksaan tanggap rasa dilakukan dengan sejumlah 20 incidental responden. Responden diminta untuk memberikan respon tentang rasa tablet hisap dekokta daun mengkudu, dengan mengisi selembar kertas yang disediakan. Setiap responden mendapatkan perlakuan yang sama untuk merasakan sampel dari ketiga formula tablet hisap dekokta daun mengkudu

e. Kandungan Flavonoid dengan Menggunakan Metode Kromatografi Lapis Tipis

Uji KLT dilakukan pada sampel tablet hisap yang digerus lalu ditambahkan pelarut aquadest lalu dipanaskan diatas penangas air hingga larut setelah itu uji flavonoid filtrat sampel pada skrining fitokimia ditotolkan pada plat silika gel G60. Dielusi dengan n-heksana : etil asetat $=2: 1$, kemudian dikeringkan diamati pada cahaya tampak, UV $254 \mathrm{~nm}$ dan $366 \mathrm{~nm}$. 
Selanjutnya plat di uapi dengan ammonia, dikeringkan dan diamati kembali pada cahaya tampak, UV $254 \mathrm{~nm}$ dan $366 \mathrm{~nm}$ (Annisa, 2010).

\section{HASIL DAN PEMBAHASAN}

Determinasi Tanaman Mengkudu, Tanaman Tebu Hijau dan Pengumpulan Bahan

Determinasi tanaman mengkudu bertujuan untuk membuktikan terhadap tanaman yang digunakan dalam penelitian dan menegaskan bahwa tanaman yang digunakan adalah tanaman daun mengkudu. Pengumpulan tanaman mengkudu dan batang tebu hijau dilakukan pada pagi hari dari tanaman mengkudu berumur lebih dari 2 tahun dan batang tebu hijau berumur 6 bulan.

\section{Hasil Pembuatan Simplisia Daun Mengkudu}

Daun mengkudu disortasi basah, kemudian dicuci dengan air mengalir, kemuadian dipotong kecil-kecil. Hasil pengujian kadar air simplisia daun mengkudu adalah sebesar 6,8\%. Hal ini menunjukkan bahwa simplisia telah memenuhi persyaratan kadar air yaitu $<10 \%$.

Pengeringan simplisia dengan nilai kadara air $<10 \%$ bertujuan untuk mencegah pertumbuhan kapang, jamur dan bakteri serta untuk menghentikan reaksi enzimatik sehingga simplisia dapat disimpan dalam waktu yang relatif lama tanpa mengalami kerusakan (Depkes RI, 1986). Hasil pembuatan simplisia daun mengkudu yaitu simplisia kering dengan kadar air 6,8\% yang diperoleh dari daun mengkudu segar sebesar 15,7 kg dan daun mengkudu kering sebesar 3,9 kg. Dari daun kering diperoleh serbuk daun mengkudu sebesar $3,54 \mathrm{~kg}$, dari hasil tersebut diperoleh rendemen daun mengkudu sebesar $4,02 \%$ dengan susut pengeringan $0,25 \%$.

\section{Rendemen Dekokta Daun Mengkudu}

Proses pembuatan dekokta daun mengkudu menggunakan metode dekokta. Pemilihan metode dekokta karena metode dekokta banyak menarik senyawa flavonoid yang terkandung di dalam daun mengkudu (Halimah, 2016).

Dekokta daun mengkudu diperoleh dari proses dekokta menggunakan pelarut aquadest. Tujuan penggunaan aquadest karena pada penelitian ini kami membuat sediaan oral sehingga kami mengusahakan menggunakan pelarut halal atau aman dikonsumsi oleh semua orang. Karena menggunakan pelarut aquadest maka bisa dipastikan dekokta yang diasilkan tidak awet (mudah ditumbuhi jamur), tidak bisa disimpan dalam waktu lama. Hasil rendemen dekokta daun mengkudu diperoleh sebesar $0,8006 \%$ yang dihasilkan dari serbuk daun mengkudu sebanyak 600 gram dengan bobot dekokta daun mengkudu sebesar $4800 \mathrm{ml}$.

\section{Hasil Pemeriksaan Sifat Fisika Dan Kimia Dekokta Daun Mengkudu Dan Air Tebu Hijau}

Dekokta daun mengkudu dan air tebu hijau diperiksa sifat fisika dan kimia meliputi: pemeriksaan organoleptis, kejernihan dan KLT. Pemeriksaan sifat fisik dilakukan dengan tujuan untuk mengetahui kualitas dekokta dan air tebu hijau yang didapat. Hasil pemeriksaan uji sifat fisik dekokta daun mengkudu dan air tebu hijau sebagai berikut :

\section{Organoleptis dan Kejernihan}

Pemeriksaan organoleptis dilakukan untuk mengetahui bentuk, warna, bau dan rasa (Depkes RI, 2000). Uji organoleptis dilakukan untuk mengetahui tampilan fisik dekokta. Data hasil pemeriksaan organoleptis dan kejernihan dekokta daun mengkudu dan air tebu hijau tertera pada tabel II.

Tabel II. Organoleptis dan Kejernihan Dekokta Daun Mengkudu dan Air Tebu

\begin{tabular}{|c|c|c|}
\hline \multirow{2}{*}{ Organoleptis } & \multicolumn{2}{|c|}{ Hasil Pemeriksaan Kejernihan } \\
\cline { 2 - 3 } & Dekokta Daun Mengkudu & Air Tebu \\
\hline Bentuk & Cair, Jernih & Cair, Jernih \\
\hline Warna & Hijau kehitaman & Hijau kekuningan \\
\hline Bau & Khas mengkudu & Khas tebu \\
\hline Rasa & Pahit & Manis \\
\hline
\end{tabular}




\section{Identifikasi Senyawa Flavonoid dalam metode KLT}

Pemeriksaan kimia dekokta daun mengkudu dilakukan untuk mengetahui adanya senyawa flavonoid dalam dekokta daun mengkudu. Fase diam silika gel G60, fase gerak n-heksana:etil asetat $=2: 1$, pembanding :quersetin. KLT dekokta daun mengkudu menghasilkan nilai $\operatorname{Rf} 0,63$ yang mendekati pembanding quersetin dengan nilai Rf 0,68 sehingga dapat disimpulkan bahwa dekokta daun mengkudu masih terdapat kandungan flavonoid. Hasil pemeriksaan uji KLT dekokta daun mengkudu dapat dilihat pada gambar 1berikut :
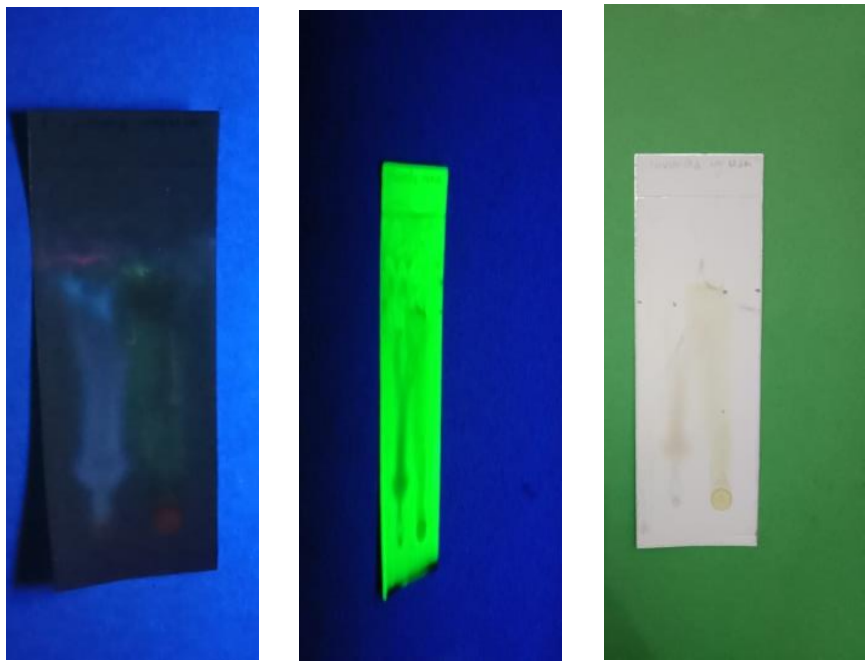

Gambar 1. Kromatogram dekokta daun mengkudu yang dilihat pada a). sinar UV 366 nm, b). sinar UV $254 \mathrm{~nm}$, c). sinar visibel

\section{Hasil Pemeriksaan Sifat Fisika dan Kimia Tablet Hisap Dekokta Daun Mengkudu}

Hasil pemeriksaan sifat fisika kimia dan tanggap rasa tablet hisap dekokta daun mengkudu meliputi: keseragaman bobot, kekerasan, waktu larut dan KLT.

\section{Keseragaman bobot}

Cara menetapkan keseragaman bobot adalah dengan menimbang 20 tablet satu persatu kemudian dihitung bobot rata-rata tiap tablet. Suatu formulasi tablet dikatakan memenuhi persyaratan keseragaman bobot jika nilai Coefficient Variation (CV) kurang dari 5\%. Semakin kecil harga \% CV maka semakin seragam tablet yang dihasilkan. Data hasil pemeriksaan keseragaman bobot tablet hisap tertera pada tabel III berikut ini:

Tabel III. Hasil Pemeriksaan Keseragaman Bobot Tablet Hisap Dekokta Daun Mengkudu dengan Pemanis Sukrosa-Air tebu, Sorbitol-Sukrosa-Air Tebu dan Aspartam-Sukrosa-Air Tebu

\begin{tabular}{|c|c|c|}
\hline \multirow{2}{*}{ Formula } & \multicolumn{2}{|c|}{ Sifat Fisik Tablet Bobot Rata-Rata } \\
\cline { 2 - 3 } & X (gram) & SD \\
\hline F1 & 2,606 & 0,0057 \\
\hline F2 & 2,603 & 0,0057 \\
\hline F3 & 2,593 & 0,0115 \\
\hline F4 & 2,307 & 0,0150 \\
\hline F5 & 2,410 & 0,0200 \\
\hline F6 & 2,502 & 0,0160 \\
\hline F7 & 2,207 & 0,0170 \\
\hline F8 & 2,381 & 0,0250 \\
\hline F9 & 2,415 & 0,0180 \\
\hline
\end{tabular}

Data keseragaman bobot pada tabel III dibandingkan dengan penyimpangan bobot tablet yang tercantum dalam Farmakope Indonesia maka tidak ada satu tablet yang menyimpang dari 5\% 
dan tidak ada satu tabletpun yang menyimpang bobotnya lebih dari $10 \%$ dari bobot rata-ratanya. Bobot rata-rata tablet tiap formula dinyatakan memenuhi persyaratan Farmakope Indonesia edisi III.

\section{Kekerasan}

Kekerasan tablet menggambarkan ketahan tablet terhadap tekanan, goncangan, dan benturan benda lain pada saat pembuatan, pengemasan dan pendistribusian (Parrott, 1971). Kekerasan tablet hisap dipersyaratkan yaitu 10-20 kg (Parrott, 1971). Data hasil pemeriksaan sifat fisik kekerasan tablet hisap tertera pada tabel IV berikut ini:

Tabel IV. Hasil Pemeriksaan Kekerasan Tablet Hisap Dekokta Daun Mengkudu dengan Pemanis Sukrosa-Air tebu, Sorbitol-Sukrosa-Air Tebu dan Aspartam-Sukrosa-Air Tebu

\begin{tabular}{|c|c|c|}
\hline Formula & \multicolumn{2}{|c|}{ Sifat Fisik Kekerasan Tablet } \\
\hline & $\mathbf{X ~ ( K g )}$ & SD \\
\hline F1 & 14.906 & 0,0305 \\
\hline F2 & 13,126 & 0,3785 \\
\hline F3 & 12,270 & 0,0200 \\
\hline F4 & 13,255 & 0,0140 \\
\hline F5 & 14,354 & 0,0520 \\
\hline F6 & 15,842 & 0,0250 \\
\hline F7 & 10,165 & 0,0070 \\
\hline F8 & 11,191 & 0,0340 \\
\hline F9 & 12,137 & 0,0290 \\
\hline
\end{tabular}

Berdasarkan data kekerasan disimpulkan bahwa ketiga formula tablet hisap memenuhi kekerasan sebagai tablet hisap Data yang diperoleh kemudian diuji normalitas dan homogenitasnya, menghasilkan data yang normal dan homogen. Analisis dilanjutkan dengan uji statistik parametrik Anova satu jalan dengan taraf kepercayaan 95\%. Nilai signifikansi yang diperoleh yaitu $0,000<0,05$ yang berarti terdapat perbedaan bermakna antara ketiga formula, maka dilanjutkan uji Tukey. Uji lanjutan Tukey menujukan nilai signifikansi $0,000<0,05$ maka dapat diartikan bahwa formula berbeda bermakna atau terdapat perbedaan.

Faktor yang mempengaruhi kekerasan tablet pada penelitian ini adalah pemanis sukrosa yang digunakan, semakin banyak sukrosa yang digunakan maka dapat meningkatkan kekerasan tablet, memperlama kecepatan disintegrasi dan menyebabkan tablet menjadi rapuh (Khankari dan Hontz, 1997). Mekanisme terjadinya proses kristalisasi atau pemadatan tablet, dimana terdapat gaya adhesi dan kohesi antara zat padat dan cair, dalam peneltian ini sukrosa dan air tebu. Setelah terjadinya gaya adhesi dan kohesi selanjutnya terbentuk gaya antar muka antara sukrosa dan air tebu. Setelah itu terbentuk jembatan padat yang dikarenakan air tebu menguap sehingga campuran menjadi keras, kemudian terjadi gaya Tarik menarik antar partikel padat (Aulton, 2007).

Penelitian Alkarim dkk, (2012) menyebutkan bahwa semakin tinggi konsentrasi sukrosa maka kekerasan tablet hisap meningkat. Selain itu sorbitol juga dapat menghasilkan tablet hisap yang memiliki waktu larut yang semakin lama dan kekerasan tinggi (Gusmayadi, 2014). Tetapi sorbitol dan aspartam tidak seperti sukrosa dimana sukrosa berperan penting dalam memberikan tingkat kekerasan dan waktu larut yang memenuhi persyaratan. Air tebu berperan sebagai pelarut tetapi jika menggunakan air tebu terlalu banyak akan menghhasilkan tablet hisap yang lembek dan lengket.

\section{Waktu larut}

Tablet hisap melarut selama 30 menit dengan suhu $37^{\circ} \mathrm{C}$ dalam $200 \mathrm{ml}$ aquadest kecepatan $50 \mathrm{rpm}$ (Allen, 2002). Data waktu larut tablet hisap dapat dilihat pada tabel V. 
Tabel V. Hasil Pemeriksaan Fisik Waktu Larut Tablet Hisap Dekokta Daun Mengkudu dengan Pemanis Sukrosa-Air tebu, Sorbitol-Sukrosa-Air Tebu dan Aspartam-Sukrosa-Air Tebu

\begin{tabular}{|c|c|c|}
\hline Formula & X (Menit) & SD \\
\hline & 19,30 & 0,1637 \\
\hline F1 & 17.35 & 0,0720 \\
\hline F2 & 16.18 & 0,0850 \\
\hline F3 & 17,26 & 0,0129 \\
\hline F4 & 18,29 & 0,0840 \\
\hline F5 & 20,29 & 0,0770 \\
\hline F6 & 15,27 & 0,1120 \\
\hline F7 & 16,27 & 0,1580 \\
\hline F8 & 18,30 & 0,1970 \\
\hline F9 & & \\
\hline
\end{tabular}

Hasil statistik Anova dapat yang berarti terdapat perbedaan yang bermakna, kemudian dilanjutkan uji Tukey. Uji lanjutan Tukey menunjukan bahwa nilai signifikansi $0,000<0,05$ yang artinya berbeda bermakna atau terdapat perbedaan.

Hasil uji tersebut menunjukkan bahwa pemanis sukrosa menyebabkan perbedaan waktu larut pada tablet hisap. Waktu larut tablet hisap juga dipengaruhi oleh kekerasan tablet hisap, sehingga semakin keras tablet hisap maka waktu larut semakin lama. Semakin banyak sukrosa yang digunakan maka tablet semakin keras dan semakin lama waktu larut tablet tersebut (Alkarim et al., 2012). Selain itu sorbitol dapat menghasilkan tablet hisap yang memiliki waktu larut yang semakin lama dan kekerasan tinggi (Gusmayadi dan Nella, 2014). Tetapi sorbitol tidak seperti sukrosa dimana sukrosa berperan penting dalam memeberikan tingkat kekerasan dan waktu larut yang memenuhi persyaratan. Pemanis aspartam yang digunakan tablet hisap dapat memberikan kekerasan semakin rendah dan waktu larut yang cepat. Air tebu berperan sebagai pelarut tetapi jika menggunakan air tebu terlalu banyak akan menghasilkan tablet hisap yang lembek dan lengket. Berdasarkan data waktu larut disimpulkan bahwa ketiga formula tablet hisap memenuhi persyaratan waktu larut tablet hisap.

\section{KLT Senyawa Flavonoid Dalam Tablet Hisap}

Hasil uji KLT tablet hisap dekokta daun mengkudu dapat dilihat pada gambar 2 berikut:
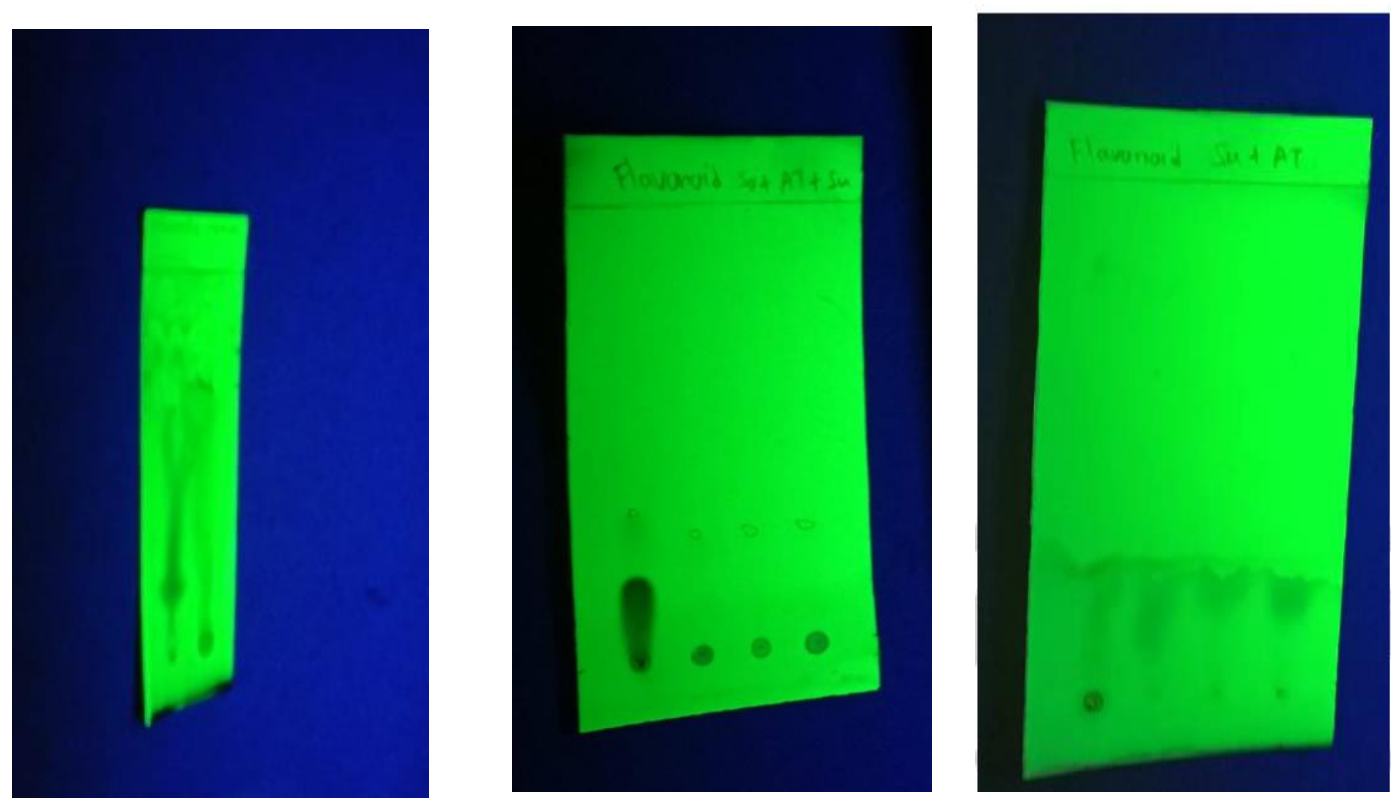


\section{Gambar 2. Kromatogram tablet hisap dekokta daun mengkudu}

Hasil KLT pada semua formula diperoleh nilai Rf 0,230; 0,230 dan 0,2179 yang mendekati pembanding quersetin dengan nilai Rf 0,230-0,30, sehingga dapat disimpulkan bahwa semua formula tablet hisap masih terdapat kandungan flavonoid.

\section{Tanggap Rasa}

Tanggap rasa dilakukan untuk mengetahui tanggapan dari incidental responden terhadap rasa dari tablet hisap yang dihasilkan. Tanggap rasa merupakan tolak ukur penting dalam pembuatan tablet hisap, karena apabila tablet hisap terasa tidak enak makan tidak akan disukai incidental responden yang menyebabkan tujuan pengobatan tidak tercapai. Uji tanggap rasa dilakukan terhadap 20 orang responden diminta untuk memberikan tanggapan rasa dengan mengisi angket yang di sediakan. Hasil uji tanggap rasa dapat dilihat pada tabel VI di bawah ini:

Tabel VI. Hasil Uji Tanggap Rasa Tablet Hisap Dekokta Daun Mengkudu dengan Pemanis Sukrosa-Air tebu, Sorbitol-Sukrosa-Air Tebu dan Aspartam-Sukrosa-Air Tebu

\begin{tabular}{|c|c|c|c|c|c|c|c|c|c|}
\hline \multirow{2}{*}{ Keterangan } & \multicolumn{9}{|c|}{ Responden } \\
\cline { 2 - 11 } & F1 & F2 & F3 & F4 & F5 & F6 & F7 & F8 & F9 \\
\hline $\begin{array}{c}\text { Dapat Diterima } \\
\text { Tidak Dapat }\end{array}$ & 19 & 1 & 0 & 14 & 15 & 18 & 12 & 15 & 17 \\
\hline Diterima & 1 & 19 & 20 & 6 & 5 & 2 & 8 & 5 & 3 \\
\hline Jumlah Responden & 20 & 20 & 20 & 20 & 20 & 20 & 20 & 20 & 20 \\
\hline Presentase & $95 \%$ & $5 \%$ & $0 \%$ & $70 \%$ & $75 \%$ & $90 \%$ & $60 \%$ & $75 \%$ & $85 \%$ \\
\hline
\end{tabular}

Persyaratan tablet hisap dapat diterima oleh konsumen apabila memiliki nilai persentase di atas $50 \%$. Hasil data uji tanggap rasa pada tabel VI, semua formula dapat diterima oleh responden. Formula memenuhi persyaratan tanggap rasa dan yang paling banyak diterima tablet hisap dengan variasi pemanis sukrosa-air tebu pada F1 dikarenakan perbandingan sukrosa yang banyak sehingga menyebabkan rasa manis pada tablet hisap sedangkan yang paling sedikit diterima tablet hisap F3 dikarenakan perbandingan sukrosa yang sedikit sehingga menyebabkan tablet hisap terasa pahit. Tetapi tablet hisap dengan variasi pemanis sorbitol-sukrosa-air tebu yang paling banyak diterima terdapat pada F6 dikarenakan perbandingan sukrosa yang banyak sehingga menyebabkan tablet mempunyai rasa yang lebih manis sedangkan tablet hisap yang paling sedikit diterima pada F4 dikarenakan perbandingan sukrosa yang sedikit sehingga menyebabkan tablet masih mempunyai rasa pahit. Pada tablet hisap dengan variasi pemanis aspartame-sukrosa-air tebu yang paling banyak diterima pada F9 dikarenakan perbandingan sukrosa yang banyak sehingga menyebabkan rasa manis pada tablet hisap sedangkan yang paling sedikit diterima tablet hisap F7 dikarenakan perbandingan sukrosa yang sedikit sehingga menyebabkan tablet hisap terasa pahit.

\section{KESIMPULAN}

1. Tablet hisap dekokta daun mengkudu dengan variasi pemanis sukrosa-air tebu, sorbitol-sukrosaair tebu, dan aspartam-sukrosa-air tebu menghasilkan sifat fisik tablet yang bobotnya seragam, sedangkan kekerasan dan waktu larutnya berbeda antar formula $(\mathrm{p}<0,05)$. Hasil uji KLT dekokta daun mengkudu dan tablet hisap terdapat kandungan flavonoid.

2. Formula yang paling banyak diterima oleh responden adalah F1 pada variasi pemanis sukrosaair tebu dan sedangkan pada variasi pemanis sorbitol-sukrosa-air tebu dan aspartam-sukrosa-air tebu pada F3 dan F9.

\section{DAFTAR PUSTAKA}

Abdul, R., Sugeng, dan R.,Hidayati,N.K., 2007, Aktivitas Antioksidan, Kandungan Fenolik Total,Dan Flavonoid Total Daun Mengkudu (Morinda citrifolia L),Agritech, 27, 4. 
Alkarim, M., Murti, Y,B., Saifullah,T.N., 2012, Formulasi Hard Candy Lozenges Ekstrak Daun Legundi (Vitex trifolia L.), Skripsi, Fakultas Farmasi, Universitas Gadjah Mada, Yogyakarta, hal 16.

Alikonis, J,J., 1979, Candy Technologi, 120-122,AVI Publishing Company Inc.,Westport Connecticut.

Allen, L.V., 2002, The Art, Science, and Technology of Pharmaceutical Compounding, Second Edition, American Pharmaceutical Association, Washington, D.C. hal 172-173, 176-177, 184-186.

Annisa, M. U., 2010, Aktivitas Antioksidan Ekstrak Buah dan Daun Mengkudu (Morinda Citrofolia)., Skripsi, Departemen Kimia, IPB, Bogor.

Aulton., 2007, Aultan's Pharmaceutics The Design And Manufacture Of Medicines, Edisi 3, ISBN

Badan Penelitian dan Pengembangan Pertanian Kementerian Pertanian, 2012, budidaya pasca panen, IAARD Press, Jakarta, hal 2,7,9.

Depkes RI, 1979, Farmakope Indonesia, Edisi III, Departemen Kesehatan Republik Indonesia, Jakarta, 7, 12, 567.

Depkes RI, 1986, Cara Pembuatan Simplisia, Departemen Kesehatan Republik Indonesia, Jakarta, 10,11 .

Depkes RI, 1995, Farmakope Indonesia, Edisi IV, Departemen Kesehatan Republik Indonesia, Jakarta.

Depkes RI, 2000, Parameter Standar Umum Ekstrak Tumbuhan Obat, Cetakan Pertama, Departemen Kesehatan Indonesia, Jakarta, 21.

Gusmayadi, Inding dan Nella Azwar, 2014, Pengaruh Kombinasi Aspartame-Sorbitol Sebagai Bahan Pemanis Terhadap Sifat Fisik Tablet Hisap Ekstrak Daun Sirih (Piper Betle L.) Secara Granulasi Basah, Fakultas Farmasi, Universitas 17 Agustus 1945.

Halimah H., 2016, Observasi Potensi Penggunaan Daun Mengkudu (Morinda Citrofolia L.) Sebagai Antibakteri, Antioksidan, dan Sumber B-Karoten, Institusi Pertanian Bogor, 4.

Hidayah, R.H dan Padiastuti, 2016, Pengaruh Variasi Konsentrasi Sukrosa Dan Sirup Glukosa Terhadap Mutu Fisik Hard Candy Ekstrak Rimpang Jahe Merah (Zingiber Officinale Rocs.), Rhizome Extract, Fakultas Farmasi Universitas Setia Budi Surakarta.

Javanmardi, J., Stushnoff, C., Locke, E. and Vivanco, J.M., 2003, Antioxidant Activity Of The Major And Total Phenolic Content Of Iranian Ocinum Accessions. Journal Of Food Chemistre 83: 547-550.

Khankari and Honzts, 1997, Binder and Solvent, in Parikh, M, (Eds.) Handbook of Pharmaceutical Granulation Technology, Volume 8, 66-67, Marcel Dekker, Inc., New York.

Koswara, Sutrisno Ir., 2009, Teknologi Pembuatan Permen, EBOOKPANGAN. COM, 60.

Parrott, E. L., 1971, Pharmaceutical Technology Fundamental Pharmaceutics, $3^{\text {rd }}$ Edition, Burgess Publishing Company, Mineapols, 82.

Rowe, R. C., Sheskey, P. J., and Owen, S. C., 2009, Handbook of Pharmaceutical Exipients, Fifth Edition, the Pharmaucetical Press and the American Pharmacists Association , 679-682, 703 707.

Van Duin Dr, C. F., 1947, Buku Ilmu Resep Praktek Dan Teori, Soeroengan, Jakarta. 